\title{
Tourists Awareness, Expectations, and Challenges Encountered in the use of Social Media Promotion of Tourist Attractions
}

\author{
MA. Cecila P. Reyes \\ Nueva Ecija University of Science and Technology, Nueva Ecija, Philippines
}

Received: 01 Oct 2021; Received in revised form: 13 Nov 2021; Accepted: 22 Nov 2021; Available online: 30 Nov 2021

\begin{abstract}
Social media marketing has increased in popularity in the tourist sector because it allows businesses to communicate directly with customers through various Internet platforms, as well as monitor and respond to client comments and assessments of services. This paper focused on the awareness of tourists about the use of social media promotions of tourist attractions. Also, this paper described the expectations of tourists in using social media promotions of tourist attractions. Furthermore, challenges encountered by tourists in using social media promotions of tourist attractions were determined. This study used a descriptive-quantitative method. A total of 89 users of social media promotions of tourist attractions in Nueva Ecija were involved in this study. Tourist respondents are aware that this is a new approach for marketing tool where tourism establishments provide not only basic information of the attractions but even reviews, answers to queries, and the management profile giving them a complete assessment of tourism establishments' performance and how satisfied are the customers. Furthermore, they expected that social media promotions could provide good customer relations and services. However, there were still challenges encountered when using this marketing strategy such as there are hidden charges, display photo advertisements are different from the actual, and some information are inaccurate as they transact to the tourism establishments. The researcher recommends that in using social media promotions, tourists should be assertive to know all the details of the tourism establishments and attractions before confirming their bookings or reservations.
\end{abstract}

Keywords-Tourism, Social Media, Tourist Attraction.

\section{INTRODUCTION}

Social media marketing has increased in popularity in the tourist sector because it allows businesses to communicate directly with customers through various Internet platforms, as well as monitor and respond to client comments and assessments of services. Tourists trusted online purchasing websites/applications because they used marketing strategies like word of mouth to increase their reputation (Santos \& Santos, 2020).

To boost the appeal of rural tourism, company owners must turn to millennials and use the tools that technology may bring in order to keep up with the digital growth of the period (Chatzigeorgiou, 2017).Tourism marketers must be encouraged to identify social media as a forum where tourists discuss their travel experiences and seek independent and reputable travel information to plan their trips (Kang \&Schuett, 2013).

Despite the fact that trip planning and tourism marketing via social media are interconnected, the relationship between social media and tourism marketing, specifically the ability of social media to increase awareness and generate interest in tourism destinations and products, has not attracted significant research attention (Hays et al., 2013).

In light with the foregoing insights, the researcher determined the awareness and expectations of tourists in using social media promotions of tourist attractions. Further, the researcher determined the challenges encountered by tourists in using social media promotions of tourist attractions. 


\section{CONCEPTUAL FRAMEWORK}

An increased emphasis on leveraging social media platforms as a distribution method has the potential to capitalize on their use as advertising channels (Hvass\&Munar, 2012). Furthermore, better integration of social media platforms will enable tourist attractions to focus their social media marketing approach.

Social media as a tourist marketing tool is increasingly persuading destination marketers that it is an essential component of marketing efforts (Királová \& Pavlíčeka, 2015).Social media may act as their marketing platform, allowing them to readily approach customers via internet access and engage in two-way conversations at their own speed (Santos, 2020).

\section{OBJECTIVES OF THE STUDY}

This study focused on the awareness of tourists about the use of social media promotions of tourist attractions. Also, this paper described the expectations of tourists in using social media promotions of tourist attractions. Furthermore, challenges encountered by tourists in using social media promotions of tourist attractions were determined.

\section{METHODOLOGY}

This study used a descriptive-quantitative method, as it is a fundamental technique to analysis that investigates the issue as it currently exists(Williams, 2007). Purposive sampling method was used in this study.In this study, 89 users of social media advertisements for tourism destinations in Nueva Ecija were polled. They were made up of 36 males and 53 females ranging in age from 18 to 33 years old and using social media platforms such as Facebook, Instagram, YouTube, and online blogs.Survey research was employed in this study because it blends scientific procedures (e.g. data analysis and interpretation)(Salaria, 2012).

\section{RESULTS AND DISCUSSIONS}

Table 1. Awareness of tourists about the use of social media promotions of tourist attractions

\begin{tabular}{|c|c|c|}
\hline Statement/s & Mean & Verbal Interpretation \\
\hline $\begin{array}{l}\text { 1. Allows a tourism establishment to disseminate information } \\
\text { more quickly. }\end{array}$ & 3.59 & Strongly Agree \\
\hline $\begin{array}{l}\text { 2. Has proven to be an excellent strategy as compared to } \\
\text { traditional promotion }\end{array}$ & 3.57 & Strongly Agree \\
\hline $\begin{array}{l}\text { 3. Enables in overcoming distance and / or other communication } \\
\text { barriers }\end{array}$ & 3.20 & Agree \\
\hline $\begin{array}{l}\text { 4. Uses effective platform in sharing their personal experiences, } \\
\text { comments, and opinions. }\end{array}$ & 3.54 & Strongly Agree \\
\hline 5. Can be used to assess performance and customer satisfaction & 3.27 & Strongly Agree \\
\hline $\begin{array}{l}\text { 6. Gives you opportunities to check the management and present } \\
\text { business content }\end{array}$ & 3.14 & Agree \\
\hline 7. Secures confidentiality of the customers' personal information & 3.17 & Agree \\
\hline General Weighted Mean & 3.35 & Strongly Agree \\
\hline
\end{tabular}

\section{Legend}

$3.25-4.00$

Verbal Interpretation

$2.50-3.24 \quad$ Agree

Strongly Agree

$1.75-2.49$

Disagree

$1.00-1.74$

Strongly Disagree

Table 1 shows the awareness of tourists about the use of social media promotions of tourist attractions. Tourist respondents got a general weighted mean of 3.35, which has a verbal interpretation of "Strongly Agree". Tourist respondents strongly agreed that they are aware that social media promotions of tourist attractions do the following: "Allows a tourism establishment to disseminate information more quickly" (mean = 3.59), "Has proven to be excellent strategy as compared to traditional promotion" $($ mean $=3.57)$, "Uses effective platform in sharing their personal experiences, comments, an/or opinions" (mean = 3.54), and "Can be used to assess performance and customer satisfaction" (mean = 3.27). Analyzing the scores, it can be declared that tourist respondents perceived that using social media promotions make it easier for them to get information from the tourist attractions they want to 
go. Furthermore, social media promotions give a new approach for marketing tool where tourism establishments provide not only basic information of the attractions but even reviews, answers to queries, and the management profile giving them a complete assessment of tourism establishments' performance and how satisfied are the customers. The analysis supports the study of Zeng (2013) that using social media to market tourism products has proven to be a successful strategy. Many countries see social media as a valuable tool for promoting their tourism industries.

Table 2. Expectations of Tourists in using Social Media Promotions of Tourist Attractions

\begin{tabular}{|c|c|c|}
\hline Statement/s & Mean & Verbal Interpretation \\
\hline 1. Paying attention to profile and cover photos. & 3.12 & Agree \\
\hline $\begin{array}{l}\text { 2. Engaging with their audience when they comment on their social } \\
\text { media messages }\end{array}$ & 3.63 & Strongly Agree \\
\hline $\begin{array}{l}\text { 3. Sharing a video that tells the story of a customer who had a } \\
\text { heartwarming experience }\end{array}$ & 2.51 & Agree \\
\hline 4. The page is visually pleasing. & 2.65 & Agree \\
\hline 5. Giving attention to customers' insights or reviews & 3.69 & Strongly Agree \\
\hline 6. Promoting of products / service through discounts & 3.11 & Agree \\
\hline 7. Hosting a competition among users for rewards & 3.20 & Agree \\
\hline 8. Making fast and accurate communication & 3.47 & Strongly Agree \\
\hline 9. Creating more personalized and customized information & 2.33 & Agree \\
\hline 10. Acknowledging complaints from the customers. & 3.62 & Strongly Agree \\
\hline General Weighted Mean & 3.13 & Agree \\
\hline
\end{tabular}

\section{Legend}

$3.25-4.00$

$2.50-3.24$

$1.75-2.49$

$1.00-1.74$

\section{Verbal Interpretation}

Strongly Agree

Agree

Disagree

Strongly Disagree
Table 2 presents the expectations of tourists in using social media promotions of tourist attractions. Based on the result, tourist respondents got a general weighted mean of 3.13 that has a verbal interpretation of "Agree". Among their expectations are as follows: "Giving attention to customers' insights or reviews" (mean = 3.69), "Engaging with their audience when they comment on their social media messages" (mean = 3.63), "Acknowledging complaints from the customers" (mean = 3.62), and "Making fast and accurate communication" (mean = 3.47).
The value of the mean demonstrates that tourism establishments as they use social media for their promotions should focus on building good customer relations and services. This requires them to engage to the messages, reviews, and complaints of the customers. The analysis validates the study of Mangold and Faulds (2009), the communications landscape is changing, and social media has taken center stage in the marketing and public relations equation.

Table 3. Challenges Encountered by Tourists in using Social Media Promotions of Tourist Attractions

\begin{tabular}{|c|c|c|}
\hline Statement/s & Mean & Verbal Interpretation \\
\hline 1. Received inaccurate information about the tourism establishment & 3.57 & Strongly Agree \\
\hline 2. Experienced spammers that caused of delayed transactions & 2.50 & Agree \\
\hline 3. Had paid hidden charges & 3.59 & Strongly Agree \\
\hline 4. Lack of parking around tourist attractions & 2.52 & Agree \\
\hline 5. Absence of good transportation system to nearby tourist spots & 3.20 & Agree \\
\hline 6. Poor telecommunications signal in the location & 2.27 & Agree \\
\hline 7. Displayed photos of tourist attraction from the social media are not the same to actual & 3.54 & Strongly Agree \\
\hline General Weighted Mean & 3.03 & Agree \\
\hline
\end{tabular}




\author{
Legend Verbal Interpretation \\ $3.25-4.00 \quad$ Strongly Agree \\ $2.50-3.24 \quad$ Agree \\ $1.75-2.49 \quad$ Disagree \\ $1.00-1.74 \quad$ Strongly Disagree
}

Table 3 displays the challenges encountered by tourists in using social media promotions of tourist attractions. Based on the results, tourist respondents got a general weighted mean of 3.03, which has a verbal interpretation of "Agree". To highlight, among the challenges encountered are as follows: "Had paid hidden charges" (mean $=3.59$ ), "Received inaccurate information about tourism establishment" (mean = 3.57), and "Displayed photos of tourist attraction from the social media are not the same to actual" (mean $=3.54$ ). The data suggests that there are still disadvantages in using social media promotions to search for tourist attractions. Some tourism establishments may post all the information at one glance in their social media. Thus, customers may encounter inaccurate information during their transactions that would eventually cause hidden charges. Furthermore, due to advanced technologies specifically in capturing the beauty of some tourist attractions, social media promotions upload / post photos that are edited or enhanced making it different to actual scenery. According to research, no one can expect social media to always produce positive results; it can sometimes lead to incorrect assumptions (Buted, Gillespie, Conti, Delgado, Marasigan, Rubico, \&Felicen, 2014). As a result, there is still a need to consider various types of aspects.

\section{CONCLUSIONS AND RECOMMENDATIONS}

Social media promotion is now the trend to market tourist attractions. This research sought to find out the awareness, expectations, and problems encountered among tourists in using social media promotions. Tourist respondents are aware that this is a new approach for marketing tool where tourism establishments provide not only basic information of the attractions but even reviews, answers to queries, and the management profile giving them a complete assessment of tourism establishments' performance and how satisfied are the customers. Furthermore, they expected that social media promotions could provide good customer relations and services. However, there were still challenges encountered when using this marketing strategy such as there are hidden charges, display photo advertisements are different from the actual, and some information are inaccurate as they transact to the tourism establishments.
The researcher recommends that in using social media promotions, tourists should be assertive to know all the details of the tourism establishments and attractions before confirming their bookings or reservations. Tourist must always check the legitimacy of the information by checking the customers' ratings, reviews, comments, and experiences. To the tourism establishments, they must provide good customer relations and services as the customers from them expect these. They must be accountable and responsible to their social media promotions especially in providing and updating information to the customers. The Department of Tourism and the local government unit where the tourism establishment must cater and intervene to some problems that may arise since this will reflect to their locality if not handled properly.

\section{REFERENCES}

[1] Buted, D. R., Gillespie, N. S., Conti, J. B., Delgado, B. A., Marasigan, R. M. P., Rubico, S. K. A., \&Felicen, S. S. (2014). Effects of social media in the tourism industry of Batangas Province. Asia Pacific Journal of Multidisciplinary Research| Vol, 2(3), 123-131.

[2] Chatzigeorgiou, C. (2017). Modelling the impact of social media influencers on behavioural intentions of millennials: The case of tourism in rural areas in Greece. Journal of Tourism, Heritage \& Services Marketing (JTHSM), 3(2), 2529.

[3] Hays, S., Page, S. J., \&Buhalis, D. (2013). Social media as a destination marketing tool: its use by national tourism organisations. Current issues in Tourism, 16(3), 211-239.

[4] Hvass, K. A., \&Munar, A. M. (2012).The takeoff of social media in tourism. Journal of vacation marketing, 18(2), 93103.

[5] Kang, M., \&Schuett, M. A. (2013). Determinants of sharing travel experiences in social media. Journal of Travel \& Tourism Marketing, 30(1-2), 93-107.

[6] Királ'ová, A., \&Pavlíčeka, A. (2015).Development of social media strategies in tourism destination. Procedia-Social and Behavioral Sciences, 175, 358-366.

[7] Mangold, W. G., \&Faulds, D. J. (2009). Social media: The new hybrid element of the promotion mix. Business horizons, 52(4), 357-365.

[8] Santos, K. E. S. (2020). Online Marketing: Benefits and Difficulties to online Business Sellers. International Journal of Advanced Engineering Research and Science, 7(3).

[9] Santos, K. E. S., \& Santos, A. R. (2020).Factors Affecting Consumer Satisfaction to Online Shopping. Journal of 
Humanities and Education Development (JHED), 2(6), 571575.

[10] Williams, C. (2007). Research methods.Journal of Business \& Economics Research (JBER), 5(3).

[11] Zeng, B. (2013). Social Media in Tourism. J Tourism Hospit 2:e125. doi:10.4172/2167-0269.1000e125 